ROZ D Z I A E 17 .

\title{
ROLA PROGRAMÓW ROLNOŚRODOWISKOWYCH W KSZTAŁTOWANIU I OCHRONIE KRAJOBRAZU ROLNICZEGO W WOJEWÓDZTWIE PODLASKIM
}

\author{
Mirosława Kozłowska-Burdziak ${ }^{1}$
}

\section{Wstęp}

Charakterystyczną cechą krajobrazu województwa podlaskiego jest jego rolniczy charakter oraz występowanie znacznych obszarów cennych przyrodniczo. Istotne jest zatem pogodzenie działalności gospodarczej realizowanej w rolnictwie, a zwłaszcza jej negatywnych skutków dla otoczenia z zachowaniem walorów środowiska przyrodniczego. Wśród instrumentów Wspólnej Polityki Rolnej, realizowanej w Polsce po roku 2004, znajdują się takie, które mają na celu wspieranie działalności rolniczej, ukierunkowanej na ochronę przyrody. Należą do nich programy rolnośrodowiskowe, zmierzające do ochrony wody i gleby, cennych przyrodniczo siedlisk oraz zachowania genetycznych cech roślin i zwierząt zagrożonych degeneracją.

Celem rozdziału jest ocena zainteresowania rolników województwa podlaskiego realizacją działań rolnośrodowiskowych od roku 2004 i próba określenia wpływu tych działań na rolniczy krajobraz województwa. W badaniach wykorzystane zostaną dane GUS, ARiMR oraz Ministerstwa Rolnictwa i Rozwoju Wsi.

\footnotetext{
${ }^{1}$ Dr hab. Mirosława Kozłowska-Burdziak, prof. UwB, Uniwersytet w Białymstoku.
} 


\subsection{Cechy krajobrazu rolniczego w województwie podlaskim}

Województwo podlaskie jest regionem rolniczym. W roku 2017 użytki rolne stanowiły tu 60,4\% powierzchni ogólnej (w kraju - 60,0\%) ${ }^{2}$. Wyższy jest także w województwie wskaźnik udziału użytków rolnych w dobrej kulturze - 99,5\%, wobec 99,1\% w kraju. Struktura użytków rolnych, a zwłaszcza wysoki udział łąk i pastwisk (w województwie podlaskim $32,4 \%$, w Polsce - 20,4\%) sprzyja produkcji bydła mlecznego i opasowego. Ma to odzwierciedlenie w pogłowiu bydła. W roku 2017 w województwie podlaskim znajdowało się 1018,3 tys. sztuk zwierząt (16,6\% stanu ogółem bydła w kraju), pod tym względem wyprzedzało je jedynie województwo mazowieckie - 1123,3 tys. sztuk zwierząt. W przeliczeniu na 100 ha użytków rolnych (UR) pogłowie bydła było najwyższe w województwie podlaskim (95,7 szt.). Prawie 46\% stada stanowiły krowy. Produkcja mleka krowiego w roku 2017 w województwie podlaskim wyniosła 20,5\% produkcji krajowej. Poza liczebnością stada wpływ na to miała przeciętna wydajność mleczna krów, która w roku 2017 wynosiła w województwie podlaskim 6090 litrów (przy średniej krajowej 5687 litrów).

W województwie podlaskim działalność rolniczą prowadzi 81,2 tys. gospodarstw rolnych. Średnia powierzchnia UR gospodarstwa wynosi tu 13,5 ha, przy średniej krajowej 10,3 ha UR. Prawie 65\% stanowią gospodarstwa w grupach obszarowych od 2 do 15 ha. Ponad połowa gospodarstw rolnych Podlasia $(54,3 \%)$ prowadzi jednocześnie produkcję roślinną i zwierzęcą, wysoki odsetek gospodarstw, bo 45,4\% specjalizuje się w produkcji roślinnej. Jednak to produkcja zwierzęca stanowi główny atut Podlasia. W roku 2016 rolnicza produkcja globalna w województwie stanowiła 6,2\% produkcji globalnej ogółem, przy czym 3,0\% globalnej produkcji roślinnej i 9,4\% globalnej produkcji zwierzęcej. Struktura rolniczej produkcji towarowej w województwie podlaskim nie ma sobie podobnej w innych województwach - 92,2\% stanowi produkcja zwierzęca, 7,8\% produkcja roślinna.

${ }^{2}$ Rocznik statystyczny województw 2018, GUS, Warszawa 2018, s. 152. 
Rolniczy charakter województwa, sąsiedztwo parków krajobrazowych oraz obszarów NATURA 2000 tworzy doskonałe warunki do rozwoju rolnictwa ekologicznego. W roku 2017 w województwie podlaskim funkcjonowało 2576 gospodarstw z certyfikatem, a 635 było w okresie konwersji. Łącznie w uprawie ekologicznej w analizowanym województwie znajdowało się 53551 ha (10,8\% użytków ekologicznych w kraju).

Podkreślić także należy, że rolnictwo w województwie podlaskim charakteryzuje się istotnym zróżnicowaniem. Część wschodnia województwa to mniej korzystna struktura demograficzna ludności wiejskiej, słabsze gleby i mniej intensywna produkcja rolna niż w gminach zachodnich.

\subsection{Działania rolnośrodowiskowe jako instrument Wspólnej Polityki Rolnej}

Wspólna Polityka Rolna (WPR) jest najstarszą polityką wspólnotową. Traktat o funkcjonowaniu Unii Europejskiej określa, że „...funkcjonowaniu i rozwojowi rynku wewnętrznego produktów rolnych musi towarzyszyć ustanowienie wspólnej polityki rolnej"3. Początkowo cele WPR zmierzały do zapewnienia samowystarczalności żywnościowej Wspólnoty. Wspomniany Traktat o funkcjonowaniu Unii Europejskiej zalicza do nich: ${ }^{4}$

- wzrost wydajności rolnictwa przez wspieranie postępu technicznego, optymalne wykorzystanie czynników produkcji - szczególnie czynnika pracy oraz przez racjonalny rozwój produkcji rolniczej;

- zapewnienie odpowiedniego poziomu życia ludności wiejskiej, zwłaszcza przez podniesienie dochodów ludności rolniczej;

- stabilizacja rynków produktów rolnych;

- zagwarantowanie bezpieczeństwa dostaw żywności;

- zapewnienie rozsądnych cen żywności dla konsumentów.

${ }^{3}$ Traktat o funkcjonowaniu Unii Europejskiej (wersja skonsolidowana), Dz.U. UE, C 326/47, 26.10.2012, art. 38, ust. 4, https://eur-lex.europa.eu/legal-content/ PL/TXT/PDF/?uri = CELEX:12012E/TXT\&from = GA [data dostępu: 23.06.2019].

${ }^{4}$ Tamże, art. 39. 
Stosowane instrumenty WPR, zmierzające z jednej strony do wspierania rozwoju rolnictwa Wspólnoty poprzez korzystny dla producentów system cen, z drugiej - ochrona rynku przed napływem produktów rolniczych spoza UE, w krótkim czasie doprowadziły do nadprodukcji żywności ${ }^{5}$. Ponadto intensywna produkcja rolna miała niekorzystny wpływ na środowisko przyrodnicze. Jednak do lat 90 . XX wieku nie funkcjonowały w Europie reguły prawne, które miałyby na celu ochronę przyrody na terenach rolniczych. Dopiero reforma MacSharry'ego z 1992 roku zapoczątkowała program zrównoważonego rozwoju, uwzględniający zachowanie w działalności rolniczej walorów krajobrazowych ${ }^{6}$.

Rozporządzeniem Rady nr 2078/92/WE o metodach gospodarowania przyjaznych dla środowiska przyrodniczego i o rozwoju obszarów wiejskich wprowadzono na terenie Unii Europejskiej tzw. programy rolnośrodowiskowe, które obejmują działania umożliwiające uzyskanie przez rolników dopłat za stosowanie korzystnych dla przyrody, tradycyjnych metod gospodarowania.

W roku 1999 wspomniane rozporządzenie zastąpiono nowym rozporządzeniem Rady nr 1257/99 w sprawie wsparcia rozwoju wsi przez Europejski Fundusz Orientacji i Gwarancji Rolnej, w którym podkreślono, że „program pomocy rolnośrodowiskowej powinien być kontynuowany w celu zachęcania rolników, by służyli społeczeństwu jako całości przez wprowadzanie lub kontynuowanie stosowania praktyk gospodarki rolnej zgodnych z rosnącą potrzebą ochrony i poprawy środowiska, zasobów

${ }^{5}$ G. Wójcik, Wspólna Polityka Rolna i jej wpływ na rozwój rolnictwa i obszarów wiejskich po akcesji do Unii Europejskiej, „Wiadomości Zootechniczne” 2011, R. XLIX, s. 62; W. Przegon, Polska wieś a Wspólna Polityka Rolna w UE, „Infrastruktura i Ekologia Terenów Wiejskich" 2008, nr 3, s. 32.

${ }^{6}$ A. Kucharska, Programy rolnośrodowiskowe z udziałem zwierząt trawożernych szansą na utrzymanie naturalnych i pótnaturalnych tąk i pastwisk oraz ich bioróżnorodności, „Chemia, Dydaktyka, Ekologia, Metrologia” 2015, R. 10, nr 1-2, s. 29

${ }^{7}$ K. Kuszewska, A.M. Fenyk, Programy rolnośrodowiskowe i fundusze Unii a kształtowanie i ochrona krajobrazu rolniczego, „Acta Scientiarum Polonorum, Administratio Locorum" 2010, nr 9(3), s. 73. 
naturalnych, gleby, różnorodności genetycznej i utrzymania stanu krajobrazu i obszarów wiejskich"».

Artykuł 22 rozporządzenia Rady nr 1257/99 określa cele polityki wspólnotowej dotyczące rolnictwa, środowiska naturalnego i warunków utrzymania zwierząt gospodarskich. Zakłada on wsparcie metod produkcji rolniczej, które będzie promowało ${ }^{9}$ :

a) sposoby użytkowania gruntów rolnych zgodne z zasadami ochrony i poprawy jakości środowiska, krajobrazu i jego elementów, zasobów naturalnych, gleby i różnorodności genetycznej;

b) przyjazną dla środowiska ekstensyfikację rolnictwa i nisko intensywne systemy wypasania zwierząt;

c) zachowanie elementów środowiska rolnego o wysokiej wartości przyrodniczej, które są zagrożone;

d) utrzymanie krajobrazu i cech historycznych gruntów rolnych;

e) stosowanie planowania środowiskowego w praktyce rolniczej;

f) poprawę warunków utrzymania zwierząt.

Programy rolnośrodowiskowe są obowiązkowe dla każdego z państw członkowskich UE, ale ich zakres oraz środki przeznaczone na współfinansowanie programów podlegają decyzji każdego z tych państw. Zasadniczym celem programów rolnośrodowiskowych jest zachęcenie rolników do prowadzenia działalności zgodnie z wymogami ochrony przyrody ${ }^{10}$. Wśród celów szczegółowych wymienia się ${ }^{11}$ :

${ }^{8}$ Rozporządzenie Rady (WE) nR 1257/1999 z dnia 17 maja 1999 r. w sprawie wsparcia rozwoju obszarów wiejskich z Europejskiego Funduszu Orientacji i Gwarancji Rolnej (EFOGR) oraz zmieniające i uchylające niektóre rozporządzenia, Dz.U. L 160 z 26.6.1999 r., s. 80, p. 31.

${ }^{9}$ Tamże, art. 22.

${ }^{10}$ Podlaski Portal Przyrodniczo Turystyczny Zielone Wrota, http://www.zielonewrota.pl/art_v.php?art $=2820 \&$ p [data dostępu: 15.06.2019].

11 https://www.arimr.gov.pl/dla-beneficjenta/biblioteka/archiwum/programy-i-dzialania-wdrozone-w-poprzednich-latach/plan-rozwoju-obszarow- 
- użytkowanie gruntów zgodnie z zasadami ochrony środowiska, ochrony i zachowania krajobrazu wiejskiego, zasobów naturalnych, gleby, wody, bioróżnorodności;

- zachowanie siedlisk o wysokiej wartości przyrodniczej;

- promowanie rolnictwa ekstensywnego;

- stosowanie w praktyce rolniczej planowania środowiskowego;

- podniesienie wśród rolników ich świadomości ekologicznej.

Programy rolnośrodowiskowe są jednym z najważniejszych instrumentów prośrodowiskowych, jakimi dysponuje Wspólna Polityka Rolna. Jest to instrument szczególnie istotny w warunkach nadmiernej eksploatacji środowiska naturalnego, z którą mamy do czynienia także w gospodarce rolnej ${ }^{12}$.

\subsection{Realizacja działań rolnośrodowiskowych w Polsce ze szczególnym uwzględnieniem województwa podlaskiego}

W rolnictwie polskim programy rolnośrodowiskowe realizowane są od momentu akcesji do UE. W Planie Rozwoju Obszarów Wiejskich na lata 2004-2006 zawarto działanie „Wspieranie przedsięwzięć rolnośrodowiskowych i poprawy dobrostanu zwierząt", na którego realizację przewidziano wydatkowanie 218,90 mln EUR (6,1\% środków przewidzianych na realizację całego PROW). Wkład środków UE w realizację programu rolnośrodowiskowego wyniósł 175,03 mln EUR (80,0\%) ${ }^{13}$.

-wiejskich-2004-2006/wspieranie-przedsiewziec-rolno-srodowiskowych-i-poprawy-dobrostanu-zwierzat.html [data dostępu: 12.03.2019].

${ }^{12} \mathrm{~S}$. Kowalczyk, $Z$ badań nad rolnictwem społecznie zrównoważonym, Rolnictwo zrównoważone $w$ erze globalizacji, szanse i zagrożenia, Instytut Ekonomiki Rolnictwa i Gospodarki Żywnościowej, PIB, Warszawa 2018, s. 64.

${ }^{13}$ https://www.arimr.gov.pl/programy-2002-2013/plan-rozwoju-obszarow-wiejskich-2004-2006.html [data dostępu: 12.06.2019]. 
Działanie rolnośrodowiskowe obejmowało siedem pakietów, z których cztery, tj. „Rolnictwo ekologiczne”, „Ochrona gleb i wód”, „Strefy buforowe”, "Zachowanie lokalnych ras zwierząt gospodarskich”, mogły być realizowane na terenie całego kraju. Pakiety: „Rolnictwo zrównoważone”, „Utrzymanie ekstensywnych łąk” i „Utrzymanie ekstensywnych pastwisk” mogły być realizowane tylko na obszarze stref priorytetowych. Strefa priorytetowa (SP) to obszar wdrażania programu rolnośrodowiskowego, który wykazywał określone problemy środowiskowe i wymagał podjęcia działań naprawczych lub ochronnych.

Wykaz gmin i obrębów geodezyjnych zaliczonych do poszczególnych stref priorytetowych zawarto w załączniku nr 3 do rozporządzenia Rady Ministrów z dnia 20 lipca 2004 r. w sprawie szczegółowych warunków i trybu udzielania pomocy finansowej na wspieranie przedsięwzięć rolnośrodowiskowych i poprawy dobrostanu zwierząt objętej planem rozwoju obszarów wiejskich ${ }^{14}$.

W pierwszym okresie programowania zainteresowanie rolników działaniami rolnośrodowiskowymi było stosunkowo niewielkie. Liczba złożonych wniosków wynosiła 83094 i stanowiła zaledwie 4,6\% gospodarstw rolnych ogółem z roku 2006.

Wśród pakietów największym zainteresowaniem cieszyła się „Ochrona gleb i wód" (wykres 17.1.). Pakiet ten charakteryzował się stosowaniem międzyplonów i miał na celu zwiększenie udziału gleb z okrywą roślinną w okresie jesienno-zimowym. Najmniej złożono wniosków na pakiet „Strefy buforowe”, który polegał na tworzeniu 2- lub 5-metrowych zadarnionych pasów odgraniczających grunty rolne od wód powierzchniowych lub terenów intensywnie użytkowanych rolniczo.

${ }^{14}$ Rozporządzenie Rady Ministrów z dnia 20 lipca 2004 r. w sprawie szczegółowych warunków i trybu udzielania pomocy finansowej na wspieranie przedsięwzięć rolnośrodowiskowych i poprawy dobrostanu zwierząt objętej planem rozwoju obszarów wiejskich, Dz.U. 2004 r. nr 174, poz. 1809, z późn. zm. 
Wykres 17.1. Struktura złożonych wniosków o wsparcie w ramach działań rolnośrodowiskowych w latach 2004-2006 w Polsce (\%)

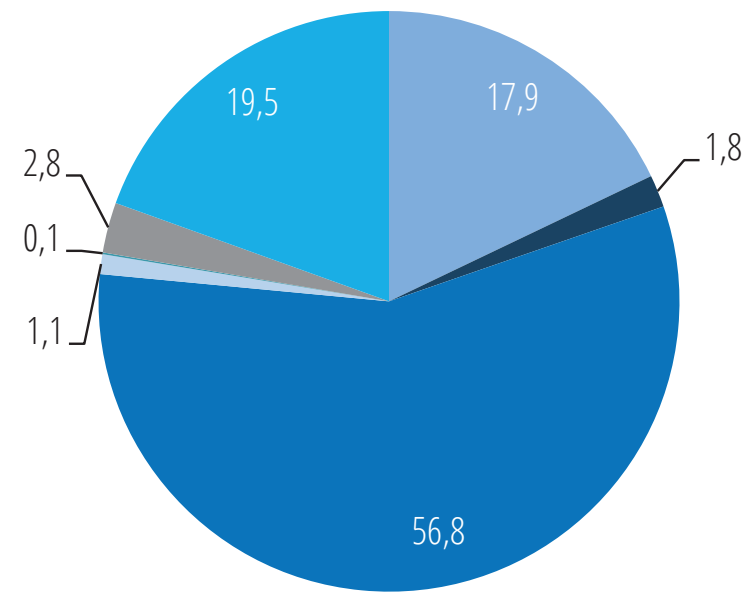

— „Utrzymanie łąk ekstensywnych"

— „Utrzymanie pastwisk ekstensywnych"

— „Ochrona gleb i wód”

"Zachowanie lokalnych ras zwierząt"

"Strefy buforowe"

- "Rolnictwo zrównoważone”

- „Rolnictwo ekologiczne”

Źródło: opracowanie własne na podstawie: Sprawozdanie z działalności ARiMR za rok 2006, https:// www.arimr.gov.pl/fileadmin/pliki/zdjecia_strony/223/Sprawozdanie_za_2006 r.pdf. [data dostępu: 13.06.2019].

Zainteresowanie programem rolnośrodowiskowym było także zróżnicowane regionalnie. Pod względem liczby złożonych wniosków dominowało województwo lubelskie. Odsetek użytków rolnych objętych programem rolnośrodowiskowym nie był tu jednak najwyższy - kształtował się na poziomie 6\% (rysunek 17.1.).

Najwyższy wskaźnik użytków rolnych objętych programem charakteryzuje w latach 2004-2006 województwa północne i zachodnie kraju, kształtował się on od 7\% do 15\%. W województwach tych do roku 1990 dominował sektor państwowy w rolnictwie i państwowe gospodarstwa rolne. W wyniku ich prywatyzacji powstały prywatne gospodarstwa rolne o znacznie większej powierzchni niż średnio w kraju. To właśnie duża powierzchnia gospodarstw rolnych tłumaczy stosunkowo niewysoką liczbę złożonych wniosków, ale wysoki odsetek użytków rolnych, biorących udział w programach rolnośrodowiskowych. 
Rysunek 17.1. Liczba złożonych wniosków wraz ze wskaźnikiem porównującym powierzchnię realizacji przedsięwzięć rolnośrodowiskowych do powierzchni użytków rolnych w województwie w latach 2004-2006

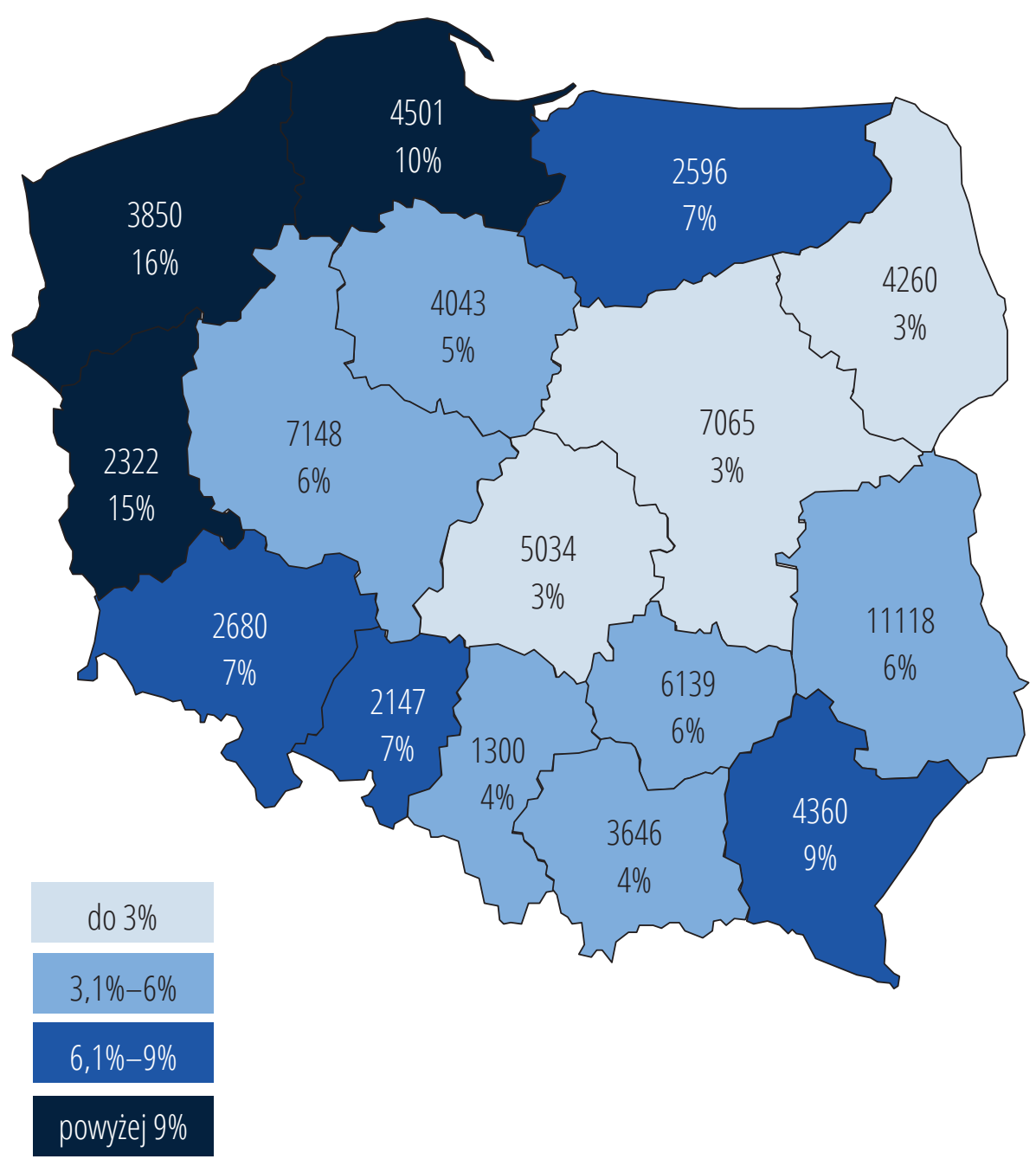

Źródło: opracowanie własne za: M. Bułkowska, K. Chmurzyńska, Wyniki realizacji PROW i SPO, Rolnictwo w latach 2004-2006, Instytut Ekonomiki Rolnictwa i Gospodarki Żywnościowej, PIB, Warszawa 2007, s. 28.

Województwo podlaskie pod względem liczby złożonych wniosków znajdowało się na 8 miejscu w kraju. Niski był również odsetek użytków 
rolnych objętych działaniami rolnośrodowiskowymi. Wynosił on zaledwie 3\%. Podobny wskaźnik charakteryzujował województwo mazowieckie i łódzkie, tam jednak liczba złożonych wniosków była wyższa. Odnosząc ją do ogólnej liczby gospodarstw rolnych w roku 2006, okazuje się, że odsetek gospodarstw, które złożyły wnioski o płatności rolnośrodowiskowe w województwie podlaskim wynosił 4,6\%, mazowieckim $-2,5 \%$ łódzkim - 3,1\%.

Zdecydowanie największym zainteresowaniem w województwie podlaskim - podobnie jak w całym kraju - cieszył się pakiet „Ochrona gleb i wód”. Udział złożonych wniosków w tym pakiecie był jednak o ponad 14 punktów procentowych (p.p.) niższy niż średnio w kraju. Wyższym natomiast odsetkiem złożonych wniosków charakteryzował się pakiet „Rolnictwo ekologiczne” oraz „Utrzymanie łąk ekstensywnych” (wykres 17.2.). W ogólnej jednak ocenie należy stwierdzić, że zainteresowanie działaniami rolnośrodowiskowymi w rolnictwie zarówno województwa podlaskiego, jak i całego kraju w latach 2004-2006 było stosunkowo niewielkie. Badania przeprowadzone w trakcie trwania PROW 2004-2006 wskazują na istotne ograniczenia w realizacji programów rolnośrodowiskowych $^{15}$.

Jednym z warunków uczestnictwa w programie była (i jest nadal) współpraca rolnika z doradcą rolnośrodowiskowym. Liczba takich doradców w stosunku w do potrzeb jest jednak niewielka. Dodatkowo wskazuje się w literaturze na problemy związane z powszechnym przekonaniem rolników o niewielkich korzyściach wynikających z zaangażowania w ochronę przyrody, czy niechęcią do przestrzegania określonych przepisów i poddawania się kontroli upoważnionych do tego instytucji ${ }^{16}$.

${ }^{15}$ G. Niewęgłowska, Zdolność rodzinnych gospodarstw rolnych do realizacji programu rolnośrodowiskowego, „Studia i Monografie” 2005, z. 130, s. 135.

${ }^{16}$ M. Bułkowska, K. Chmurzyńska, Wyniki realizacji PROW i SPO „Rolnictwo” w latach 2004-2006, Instytut Ekonomiki Rolnictwa i Gospodarki Żywnościowej, PIB, Warszawa 2007, s. 31. 
Wykres 17.2. Struktura złożonych wniosków o wsparcie w ramach działań rolnośrodowiskowych w latach 2004-2006 w województwie podlaskim (\%)

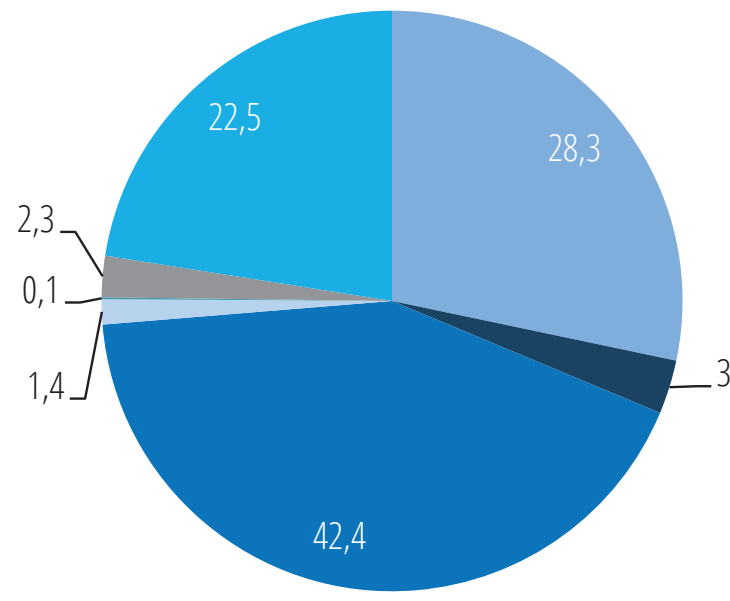

„Utrzymanie łąk ekstensywnych"

— „Utrzymanie pastwisk ekstensywnych"

—,Ochrona gleb i wód”

_Zachowanie lokalnych ras zwierząt"

- "Strefy buforowe”

— "Rolnictwo zrównoważone”

„ „Rolnictwo ekologiczne”

Źródło: opracowanie własne na podstawie: Sprawozdanie z działalności ARiMR za rok 2006, https:// www.arimr.gov.pl/fileadmin/pliki/zdjecia_strony/223/Sprawozdanie_za_2006 r.pdf [data dostępu: 13.06.2019].

W PROW na lata 2004-2006 na sfinansowanie siedmiu programów rolnośrodowiskowych (tzw. pakietów) przewidziano początkowo blisko $350 \mathrm{mln}$ euro (około $115 \mathrm{mln}$ euro rocznie). Kwotę tę zmniejszono wkrótce do $219 \mathrm{mln}$ euro (73 mln euro rocznie). Ocenia się, że jak na pierwsze lata realizacji były to kwoty wysokie, ale mające również charakter pilotażowy. W ocenie realizacji PROW 2004-2006 stwierdzono, że Polska jest przygotowana organizacyjnie do prowadzenia programów rolnośrodowiskowych na dużą skalę. Świadczyła o tym zarówno liczba gospodarstw uczestniczących w programach w latach 2004-2006 (69 tys.), jak i obszar, na którym były realizowane $-1 \mathrm{mln}$ ha użytków rolnych ${ }^{17}$.

17 J. Rowiński, Program Rozwoju Obszarów Wiejskich na lata 2007-2013, Analiza zatwierdzonej wersji programu i pierwszych lat realizacji, IERiGŻ, PIB, Warszawa 2008, s. 73. 
W Programie Rozwoju Obszarów Wiejskich na lata 2007-2013 lista działań rolnośrodowiskowych została rozszerzona z dotychczasowych siedmiu do dziewięciu. Zgodnie z rozporządzeniem Ministra Rolnictwa i Rozwoju Wsi z dnia 28 lutego 2008 roku w sprawie szczegółowych warunków i trybu przyznawania pomocy finansowej w ramach działania „Program rolnośrodowiskowy” objętego Programem Rozwoju Obszarów Wiejskich na lata 2007-2013 zobowiązanie rolnośrodowiskowe mogło być realizowane w ramach co najmniej jednego z następujących pakietów ${ }^{18}$ :

- „Rolnictwo zrównoważone”,

- „Rolnictwo ekologiczne”,

- „Ekstensywne trwałe użytki zielone”,

- „Ochrona zagrożonych gatunków ptaków i siedlisk przyrodniczych poza obszarami NATURA 2000",

- „Ochrona zagrożonych gatunków ptaków i siedlisk przyrodniczych na obszarach NATURA 2000",

- „Zachowanie zagrożonych zasobów genetycznych roślin w rolnictwie”,

- „Zachowanie zagrożonych zasobów genetycznych zwierząt w rolnictwie”,

- „Ochrona gleb i wód”,

- „Strefy buforowe”.

W każdym pakiecie określono warianty rolnośrodowiskowe, ich wybór zobowiązywał rolników do realizacji szczegółowych zadań określonych we wspomnianym rozporządzeniu. W latach 2007-2013 znacząco wzrosło zainteresowanie rolników działaniami rolnośrodowiskowymi, co wynika chociażby z liczby złożonych wniosków, która w stosunku do poprzedniego okresu programowania wzrosła o prawie $70 \%{ }^{19}$. W województwie podlaskim wzrost

${ }^{18}$ Rozporządzenie Ministra Rolnictwa i Rozwoju Wsi z dnia 28 lutego 2008 r. w sprawie szczegółowych warunków i trybu przyznawania pomocy finansowej w ramach działania „Program rolnośrodowiskowy” objętego Programem Rozwoju Obszarów Wiejskich na lata 2007-2013, Dz.U. 2008 r. nr 34, poz. 200, § 4.1.

${ }^{19}$ Sprawozdanie z działalności ARiMR za rok 2013, s. 172, https://www.arimr. gov.pl/fileadmin/pliki/zdjecia_strony/223/Sprawozdanie_ARiMR_za_2013.pdf [data dostępu: 14.06.2019]. 
zainteresowania działaniami rolnośrodowiskowymi był jednym z najwyższych - liczba złożonych wniosków wzrosła w stosunku do lat 2004-2006 o prawie 140\% (wykres 17.3.). Tym samym województwo podlaskie pod względem liczby złożonych wniosków znalazło się na piątym miejscu.

Wykres 17.3. Wzrost liczby złożonych wniosków o płatności rolnośrodowiskowe i liczby beneficjentów w latach 2007-2013 w porównaniu do lat 2004-2006 (\%)

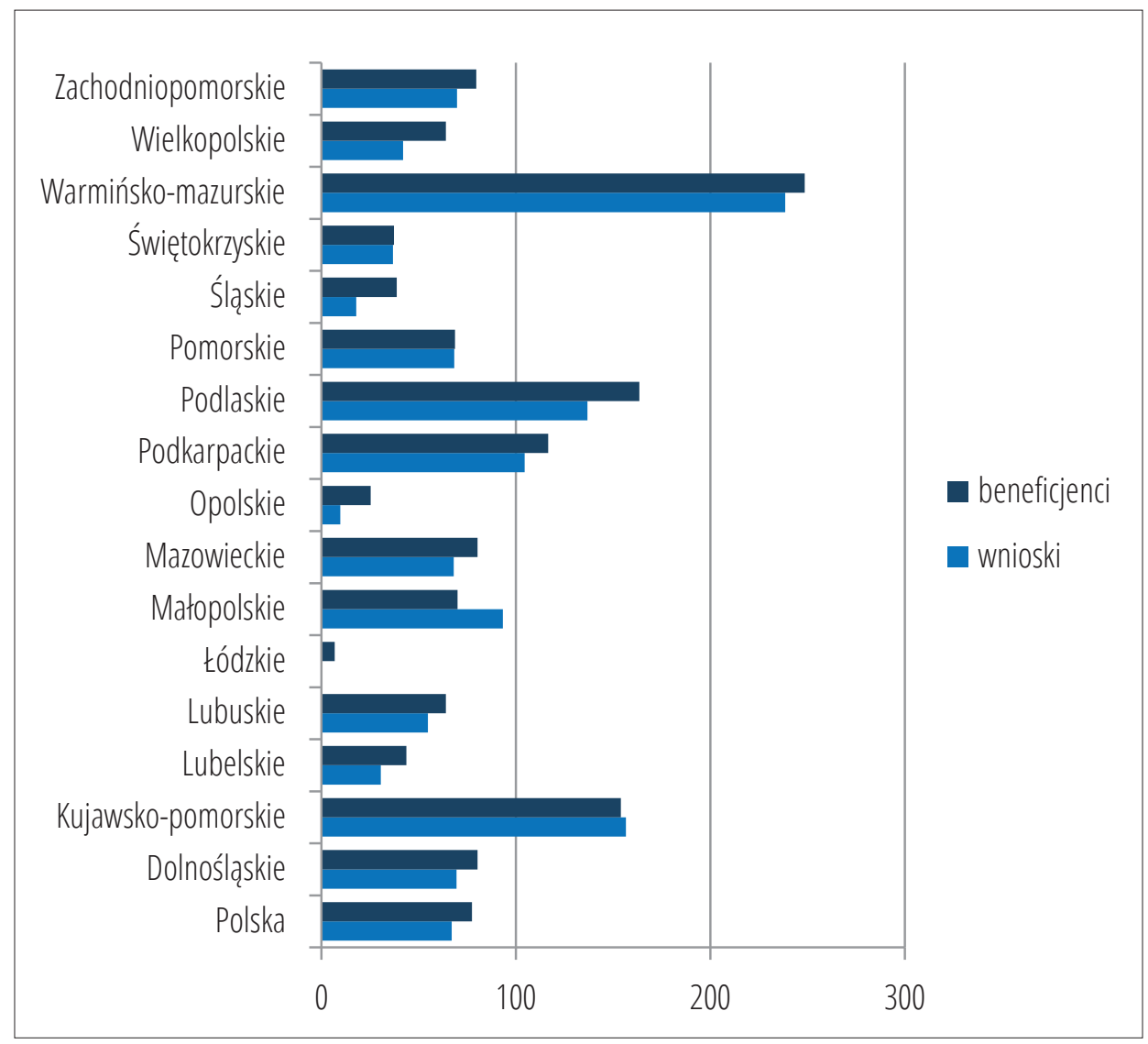

Źródło: opracowanie własne na podstawie: Sprawozdanie z działalności ARiMR za rok 2013, s. 197,198, https://www.arimr.gov.pl/fileadmin/pliki/zdjecia_strony/223/Sprawozdanie_ ARiMR_za_2013.pdf [data dostępu: 14.06.2019].

Podkreślić należy, że liczba złożonych wniosków jest istotnie wyższa od liczby beneficjentów z uwagi na to, że zasady korzystania z płatności 
rolnośrodowiskowych dopuszczają ubieganie się o wsparcie z większej liczby pakietów. W większości województw to jednak liczba beneficjentów charakteryzuje się wyższym wzrostem (niż liczba złożonych wniosków) w latach 2007-2013, w stosunku do poprzedniego okresu programowania. Świadczy to, że rolnicy, widząc przykład sąsiadów realizujących płatności rolnośrodowiskowe, sami przekonują się do podejmowania takich działań.

W całym kraju łącznie od 2004 roku najwięcej środków finansowych przeznaczono na realizację pakietu 8 „Ochrona gleb i wód” (wykres 17.4.). W okresie programowania 2007-2013 działanie to cieszyło się nieco mniejszym zainteresowaniem niż w okresie poprzednim. Wzrosło natomiast zainteresowanie pakietem 2 „Rolnictwo ekologiczne” oraz pakietem 1 „Rolnictwo zrównoważone”.

Wykres 17.4. Struktura wsparcia rolnośrodowiskowego udzielonego przez ARiMR (w mln zł), w podziale na poszczególne pakiety w Działaniu 214 Program rolnośrodowiskowy, w ramach zobowiązań 2007-2013 i 20042006, narastająco według stanu na 31 grudnia 2013 roku

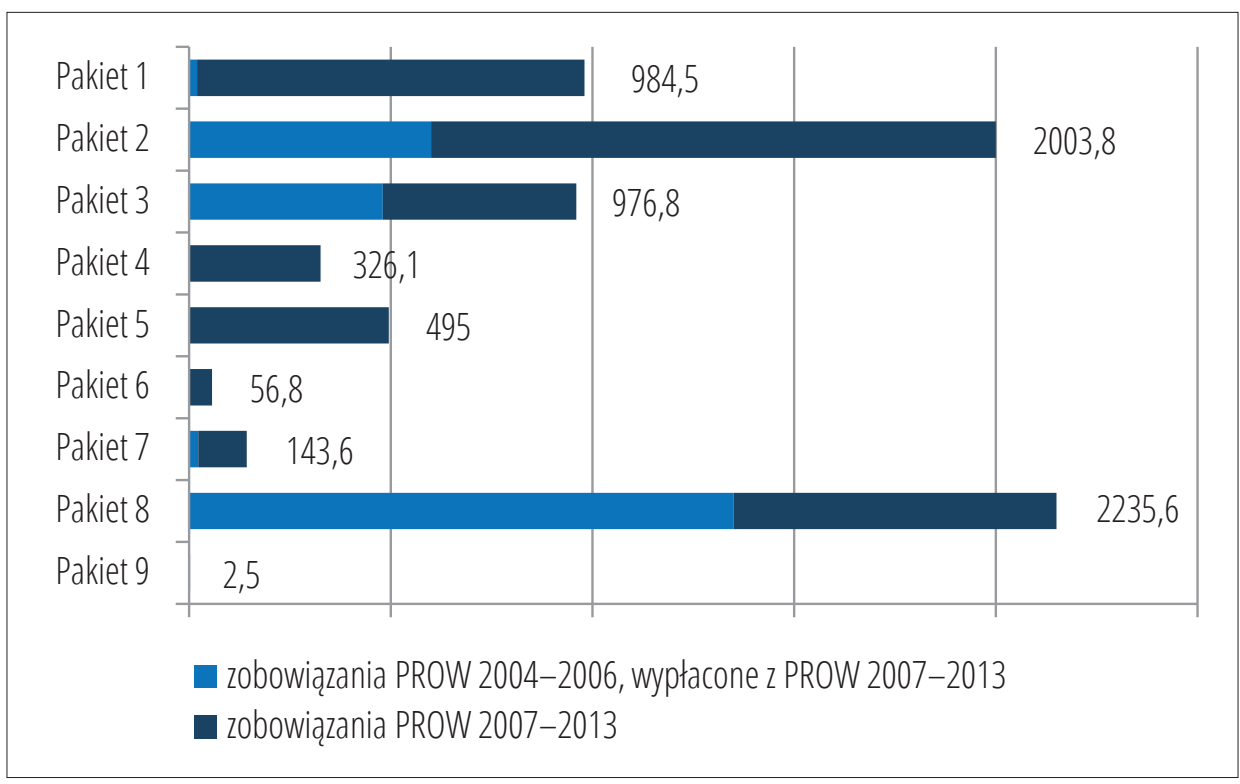

Źródło: opracowanie własne na podstawie: Sprawozdanie z działalności ARiMR za rok 2013, s. 66, https://www.arimr.gov.pl/fileadmin/pliki/zdjecia_strony/223/Sprawozdanie_ARiMR_ za_2013.pdf [data dostępu 14.06.2019]. 
W województwie podlaskim w roku 2011 największy areał realizacji płatności rolnośrodowiskowych objął pakiet 2 „Rolnictwo ekologiczne”. Realizowano go na powierzchni przekraczającej 50 tys. ha (4,7\% UR ogółem w województwie podlaskim). Na obszarze przekraczającym 20 tys. ha realizowano pakiet „Rolnictwo zrównoważone” oraz „Utrzymanie łąk” i „Utrzymanie pastwisk ekstensywnych”. Prawie 40 tys. ha objętych było realizacją pakietu „Ochrona gleb i wód”20. Łączna powierzchnia UR w województwie podlaskim objęta programami rolnośrodowiskowymi w roku 2011 przekraczała 150 tys., co stanowiło prawie 14\% UR województwa.

Ochrona środowiska przyrodniczego i promowanie praktyk rolniczych, które tej ochronie sprzyjają, jest celem Wspólnej Polityki Rolnej, realizowanym także w kolejnym okresie programowania - w latach 2014-2020. Wszystkie państwa członkowskie UE realizują ten cel poprzez wdrażanie działań rolnośrodowiskowo-klimatycznych. Działania te w latach 2014-2020, podobnie jak w okresach poprzednich, polegają na stosowaniu płatności rekompensujących rolnikom poniesione przez nich dodatkowe koszty (utracone dochody) w związku ze stosowaniem metod produkcji sprzyjających zachowaniu różnorodności biologicznej, krajobrazu oraz zasobów środowiska przyrodniczego, przede wszystkim gleby i wody ${ }^{21}$.

W Programie Rozwoju Obszarów Wiejskich na lata 2014-2020 przewidziano do realizacji 7 pakietów rolnośrodowiskowo-klimatycznych, a w ich ramach szczegółowe warianty ${ }^{22}$ :

1. „Rolnictwo zrównoważone”;

2. „Ochrona gleb i wód”;

3. „Zachowanie sadów tradycyjnych odmian drzew owocowych”;

${ }^{20}$ A. Pawlewicz, P. Bórawski, Realizacja programu rolnośrodowiskowego $w$ Polsce, „Roczniki Naukowe SERiA” 2013, t. XV, z. 2, s. 274.

${ }^{21}$ Przewodnik po Działaniu Rolnośrodowiskowo-Klimatycznym, PROW 2014-2010, Ministerstwo Rolnictwa i Rozwoju Wsi, Warszawa 2017, s. 4.

22 Program Rozwoju Obszarów Wiejskich na lata 2014-2020, Ministerstwo Rolnictwa i Rozwoju Wsi, Warszawa, 12 grudnia 2014, s. 17-18. 
4. „Cenne siedliska i zagrożone gatunki ptaków na obszarach NATURA 2000";

5. „Cenne siedliska poza obszarami NATURA 2000”;

6. „Zachowanie zagrożonych zasobów genetycznych roślin w rolnictwie”;

7. „Zachowanie zagrożonych zasobów genetycznych zwierząt w rolnictwie”.

Rolnictwo ekologiczne, które w latach 2004-2006 i 2007-2013 było jednym z pakietów rolnośrodowiskowych w PROW 2014-2020 jest odrębnym działaniem (działanie 11), ale również, jak do tej pory, ukierunkowanym na zachowanie różnorodności biologicznej i krajobrazu oraz ochronę gleby i wód.

Pod względem wysokości wsparcia w ramach działań rolnośrodowiskowo-klimatycznych województwo podlaskie z kwotą 197,8 mln zł znajduje się na siódmym miejscu w kraju (równolegle z województwem podkarpackim), pod względem liczby beneficjentów (8,3 tys.) zajmuje miejsce trzecie (równolegle $\mathrm{z}$ województwem wielkopolskim) (wykres 17.5.). Liczba złożonych wniosków o płatności w ramach działań rolnośrodowiskowo-klimatycznych w województwie podlaskim była jednak w 2018 roku niższa o 12\% w porównaniu do okresu 2007-2013, co może świadczyć o słabnącym zainteresowaniu rolników pozyskiwaniem tego rodzaju wsparcia. Województwo podlaskie nie jest w tym względzie wyjątkiem - takie zjawisko występuje w połowie województw naszego kraju.

Pakietem, który na terenie województwa podlaskiego cieszy się największym zainteresowaniem, jest pakiet 4: „Cenne siedliska i zagrożone gatunki ptaków na obszarach NATURA 2000”, co jest niewątpliwie związane z dużą powierzchnią województwa, na której te obszary ochrony zostały wytyczone (obszary NATURA 2000 to blisko 40\% powierzchni województwa podlaskiego i wyznaczane są kolejne ${ }^{23}$ ).

${ }^{23}$ NATURA 2000: Dwa nowe obszary na terenie województwa podlaskiego, https:// poranny.pl/natura-2000-dwa-nowe-obszary-na-terenie-wojewodztwa-podlaskiego/ ar/5342118 [data dostępu: 10.07.2019]. 
Wykres 17.5. Kwota wsparcia (w mln zł) i liczba beneficjentów (w tys.) działania rolnośrodowiskowo-klimatycznego, według województw, narastająco, według stanu na 31 grudnia 2018 roku

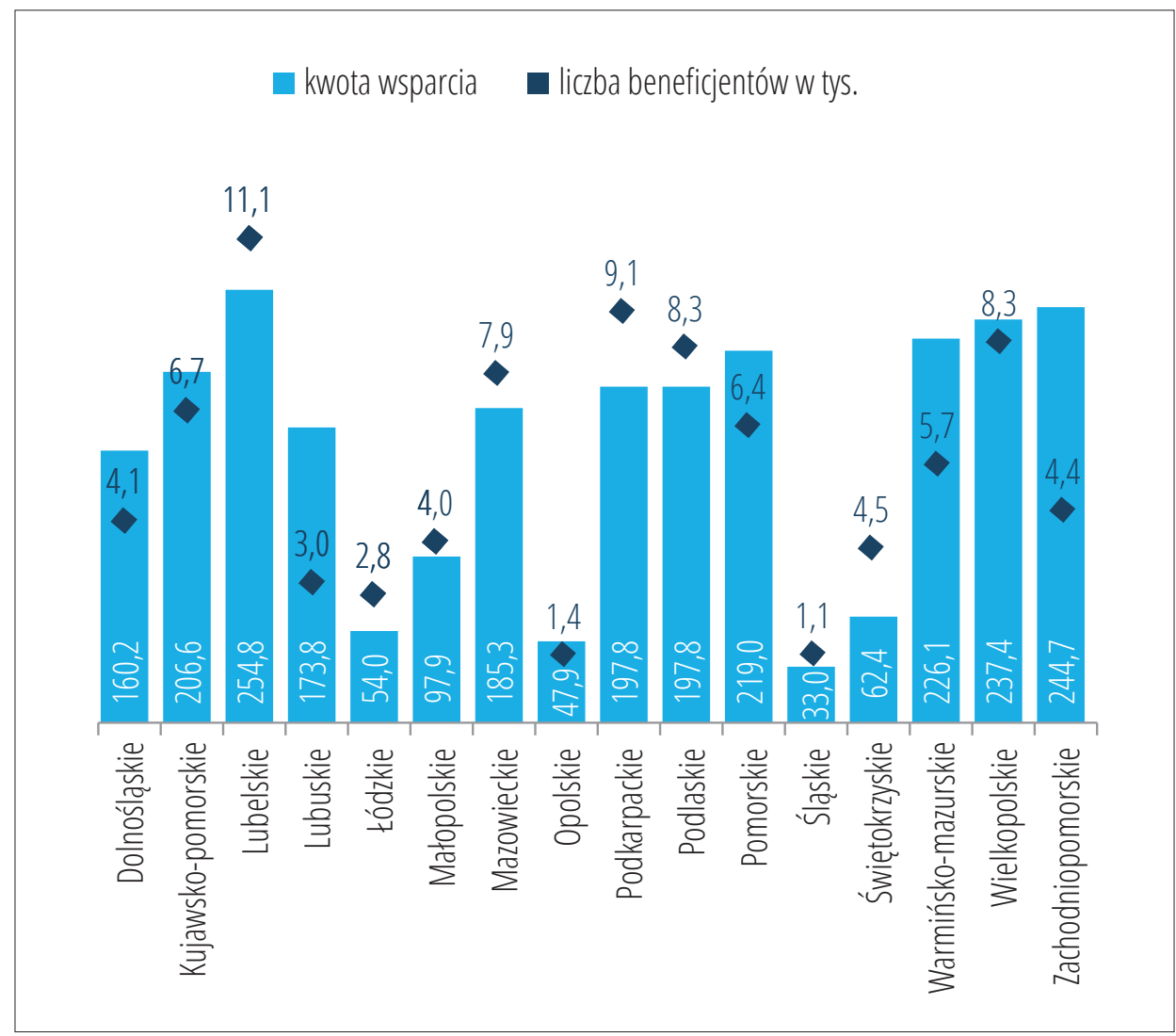

Źródło: opracowanie własne na podstawie: Sprawozdanie z działalności ARiMR za rok 2018, ARiMR, Warszawa 2019, s. 68, https://www.arimr.gov.pl/fileadmin/pliki/zdjecia_strony/223/Sprawozdanie_z_dzialalnosci_ARiMR_2018.pdf [data dostępu: 26.06.2019].

Województwo podlaskie należy do czołówki pod względem zainteresowania rolników działaniami rolnośrodowiskowymi. Biorąc pod uwagę wszystkie działania w poszczególnych okresach programowania, odsetek beneficjentów w ogólnej liczbie gospodarstw ${ }^{24}$ wynosi tu 10,3\%

${ }^{24}$ Odniesienie do ogólnej liczby gospodarstw w kraju i w poszczególnych województwach według stanu na koniec grudnia 2016 roku. 
(wykres 17.6.). Wyższym odsetkiem charakteryzują się tylko te województwa, w których przed rokiem 1990 dominował sektor państwowy w rolnictwie: pomorskie, zachodniopomorskie, kujawsko-pomorskie, warmińsko-mazurskie i lubuskie. Może to wynikać z większej przedsiębiorczości rolników z tych województw, którzy już uczestnicząc w procesie prywatyzacji majątku byłych Państwowych Gospodarstw Rolnych wykazali się większą przedsiębiorczością niż wielu rolników z innych regionów kraju.

Wykres 17.6. Odsetek beneficjentów programów rolnośrodowiskowych i rolnictwa ekologicznego po roku 2004 w Polsce, w ogólnej liczbie gospodarstw rolnych (liczba gospodarstw według stanu na koniec 2016 roku) (\%)

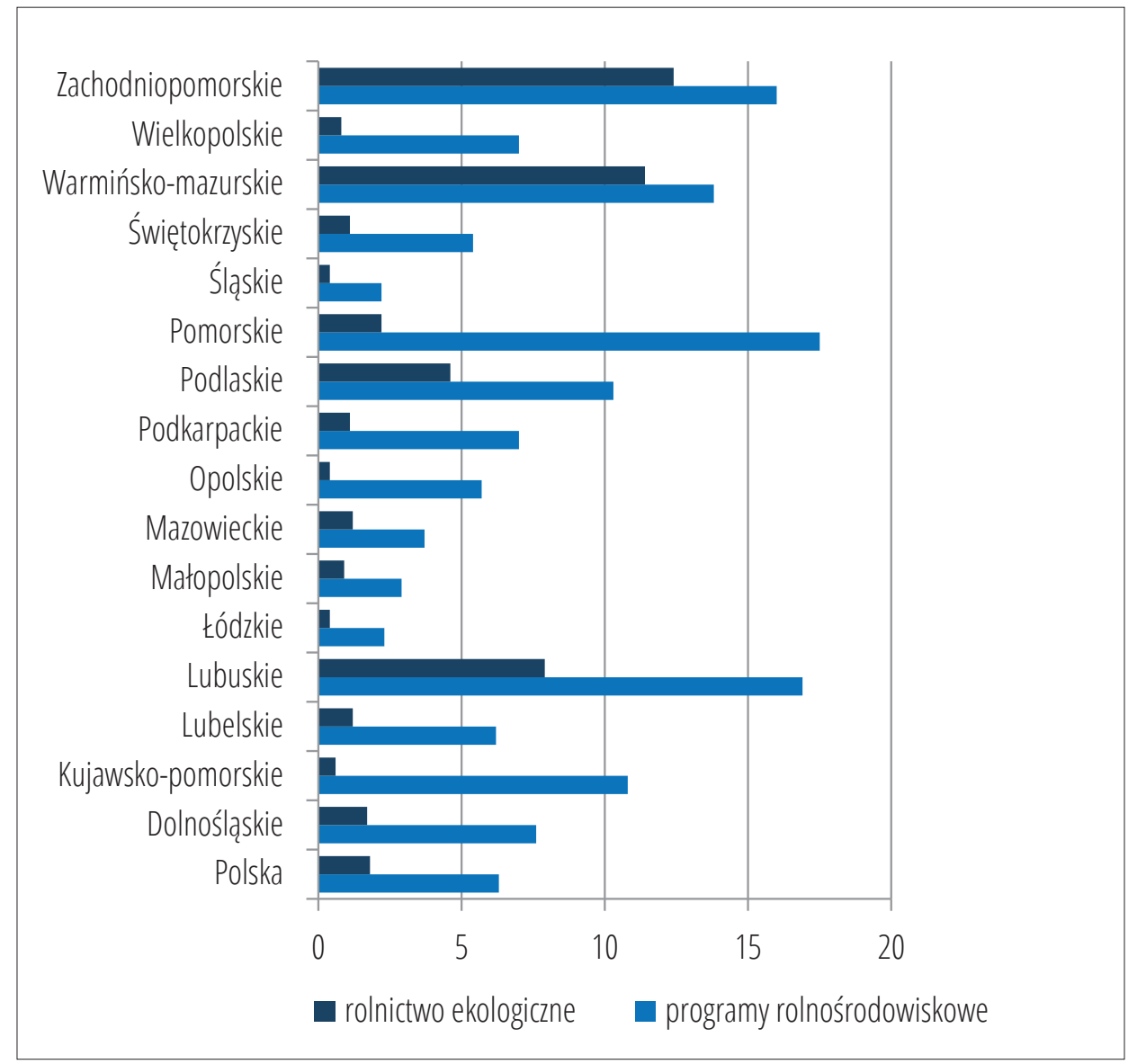

Źródło: opracowanie własne na podstawie danych ARIMR oraz GUS. 
W działaniu „Rolnictwo ekologiczne” przewidziano wsparcie finansowe w ramach poszczególnych pakietów zarówno dla gospodarstw posiadających certyfikat, jak i tych, które są w okresie konwersji na ekologiczne metody produkcji. Pod względem liczby beneficjentów korzystających z tego działania województwo podlaskie zajmuje drugie miejsce w kraju po województwie warmińsko-mazurskim. Pod względem wysokości wsparcia zajmuje miejsce trzecie - po warmińsko-mazurskim i zachodniopomorskim. Wysoki jest także odsetek beneficjentów działania w ogólnej liczbie gospodarstw - wynosi 4,6\% przy średniej dla kraju 1,8\% (wykres 17.6.).

Badania przeprowadzone w 2018 roku wśród gospodarstw ekologicznych Podlasia wskazują, że cechą charakterystyczną tego rolnictwa jest jednak niski poziom produkcji ekologicznej, większość upraw ekologicznych stanowią użytki zielone. Zainteresowanie ekologicznymi metodami produkcji związane jest w większym stopniu z uzyskaniem wsparcia ze środków unijnych niż z produkcją produktów rolnych na rynek ${ }^{25}$.

\section{Podsumowanie}

Realizacja Wspólnej Polityki Rolnej w UE w stosunkowo krótkim czasie doprowadziła do nadprodukcji żywności, co skutkowało wzrostem i tak wysokich nakładów ponoszonych we Wspólnocie na realizację działań interwencyjnych o koszty przechowywania i zagospodarowania nadwyżek żywności. Polityka intensyfikacji produkcji rolnej dodatkowo negatywnie oddziaływała na środowisko przyrodnicze. Dopiero jednak od 1992 roku

${ }^{25}$ R. Przygodzka, M. Kozłowska-Burdziak, M. Łajewski, Analiza opłacalności produkcji i dystrybucji produktów ekologicznych $w$ województwie podlaskim z wykorzystaniem modeli krótkich łańcuchów dostaw, Ekspertyza opracowana w ramach projektu pn.: „Analiza opłacalności produkcji i dystrybucji produktów ekologicznych w województwie podlaskim z wykorzystaniem wybranych modeli krótkich łańcuchów dostaw", finansowanego ze środków Krajowej Sieci Obszarów Wiejskich (KSOW) w ramach Schematu II Pomocy Technicznej Programu Rozwoju Obszarów Wiejskich na lata 2014-2020 (umowa nr ROR-II/KSOW-N-13/2018), Białystok 2018, s. 135. 
w instrumentach Wspólnej Polityki Rolnej na znaczeniu zyskują te, których celem jest wzrost ekologicznej świadomości producentów rolnych oraz ochrona krajobrazu rolniczego. Do grupy takich instrumentów należą działania rolnośrodowiskowe.

W Polsce działania rolnośrodowiskowe wprowadzono wraz z akcesją do UE. Ich zasadniczym celem jest rekompensata dla producentów rolnych utraconych korzyści, związanych z ekstensyfikacją produkcji rolnej czy wyłączeniem niektórych obszarów z produkcji rolnej.

Województwo podlaskie należy do tych regionów Polski, w których zainteresowanie programami rolnośrodowiskowymi jest znaczne. Dużą popularnością w poszczególnych okresach programowania cieszą się pakiety dotyczące ochrony gleb i wód, rolnictwa ekologicznego, utrzymywania łąk ekstensywnych oraz tzw. pakiety przyrodnicze, których celem jest ochrona siedlisk ptaków i roślin na obszarach NATURA 2000.

Wydaje się, że w rolnictwie intensywnym, ukierunkowanym na produkcję mleka, działania rolnośrodowiskowe nie przyniosą istotnych zmian w sposobie gospodarowania, a co za tym idzie i w krajobrazie rolniczym. Taka możliwość zapewne by istniała w przypadku rozwiniętego przetwórstwa mleka pochodzącego z gospodarstw ekologicznych. Jak na razie jednak skala produkcji mleka ekologicznego i jego przetworów w województwie podlaskim jest niewielka.

Programy rolnośrodowiskowe są z pewnością istotnym czynnikiem oddziałującym na krajobraz rolniczy wschodniej części województwa, objętej obszarem NATURA 2000. Dla rolników z tych terenów płatności z tytułu zobowiązań rolnośrodowiskowych są korzystną alternatywą niepewnych dochodów rolniczych, związanych z trudnymi warunkami produkcji rolniczej. 